\title{
Positron emission tomography imaging of amyloid-beta plaque deposition: a decade of translation
}

\author{
Julie C Price ${ }^{1 *}$, Chester A Mathis ${ }^{1}$, William E Klunk ${ }^{2}$ \\ From 2012 Sino-American Symposium on Clinical and Translational Medicine (SAS-CTM) \\ Shanghai, China. 27-29 June 2012
}

Positron emission tomography (PET) radiotracer developments over the past decade have enabled in vivo measurement of amyloid-beta (A $\beta$ ) plaque deposition, a key neuropathological hallmark of Alzheimer's disease (AD). This presentation will provide an overview of the translational research path for one of the most widely used PET $\mathrm{A} \beta$ imaging agents, ${ }^{11} \mathrm{C}$-lableled Pittsburgh compound-B $\left(\left[{ }^{11} \mathrm{C}\right] \mathrm{PiB}\right)$. Early preclinical ex-vivo characterization revealed the capacity of $\left[{ }^{11} \mathrm{C}\right] \mathrm{PiB}$ to bind to fibrillar $\mathrm{A} \beta$ plaques [1]. Real-time in vivo multiphoton microscopy demonstrated that $\left[{ }^{11} \mathrm{C}\right] \mathrm{PiB}$ labeled individual $\mathrm{A} \beta$ plaques in transgenic mouse models of $\mathrm{AD}$ [2]. Human proof-ofconcept studies then showed nearly 2 -fold greater uptake of $\left[{ }^{11} \mathrm{C}\right] \mathrm{PiB}$ in $\mathrm{AD}$ patients relative to controls in areas of brain known to contain amyloid in AD (frontal cortex, $\mathrm{p}<0.0001$ ), while retention was equivalent for both groups in areas known to be relatively unaffected by amyloid deposition (subcortical white matter, pons, cerebellum; $\mathrm{p}>0.2$ ) [3]. These semi-quantitative studies were followed by fully quantitative arterial-based kinetic modeling PET studies that supported the validity of simplified (nonarterial) $\left[{ }^{11} \mathrm{C}\right] \mathrm{PiB}$ PET retention outcomes that exhibited good test-retest reliability (5-10\%) needed for improved study feasibility for clinical application on cross-sectional and longitudinal bases [4] and for large collaborative multi-site studies, such as the Alzheimer's disease neuroimaging initiative (ADNI).

Early translational findings include cross-sectional evidence of amyloid deposition (i.e., $\left[{ }^{11} \mathrm{C}\right] \mathrm{PiB}$ retention) in $20-30 \%$ of cognitively normal elderly controls, variable retention in subjects with mild cognitive impairment

\footnotetext{
* Correspondence: pricjc@upmc.edu

'Departments of Radiology, University of Pittsburgh, Pittsburgh PA, 15213, USA

Full list of author information is available at the end of the article
}

(MCI) that ranged from negligible to AD-like levels and additional findings in those at risk for the development of $\mathrm{AD}$ [[5], for review]. Emerging longitudinal results indicate small significant increases in $\left[{ }^{11} \mathrm{C}\right] \mathrm{PiB}$ retention in $\mathrm{AD}$ and $\mathrm{MCI}$ groups, and in controls who had high baseline retention [6]. Efforts are ongoing to establish relationships between in vivo imaging measures and post-mortem measures of $A \beta$ deposition in those scanned with $\left[{ }^{11} \mathrm{C}\right] \mathrm{PiB}$ PET imaging before death. Anti-amyloid therapies have shown promise based on $\left[{ }^{11} \mathrm{C}\right] \mathrm{PiB}$ PET imaging results in early treatment trials. Lastly, the development of ${ }^{18} \mathrm{~F}$-labeled $\mathrm{A} \beta$ imaging agents (several-fold longer radioactive half-life than ${ }^{11} \mathrm{C}$ ) has allowed greater distribution and translational capability, with one such agent recently being approved by the U.S. Food and Drug Administration for use in the rejection of $\mathrm{AD}$ diagnosis in patients under evaluation for $\mathrm{AD}$. A decade of translation has further clarified the need for sensitive early detection of AD pathophysiology in order to identify those who might benefit most from future therapeutic intervention.

\footnotetext{
Author details

'Departments of Radiology, University of Pittsburgh, Pittsburgh PA, 15213, USA. ${ }^{2}$ Departments of Psychiatry, University of Pittsburgh, Pittsburgh PA, 15213, USA.

Published: 17 October 2012

\section{References}

1. Mathis CA, Wang Y, Holt DP, et al: Synthesis and evaluation of 11Clabeled 6 substituted 2-arylbenzothiazoles as amyloid imaging agents. J Med Chem 2003, 46:2740-54.

2. Bacskai BJ, Hickey GA, Skoch J, et al: Four-dimensional multiphoton imaging of brain entry, amyloid binding, and clearance of an amyloidbeta ligand in transgenic mice. Proc Natl Acad Sci 2003, 100:12462-7.

3. Klunk WE, Engler $H$, Nordberg A, et al: Imaging brain amyloid in Alzheimer's disease with Pittsburgh Compound-B. Ann Neurol 2004, 55:306-19.
} 
4. Price JC, Klunk WE, Lopresti BJ, et al: Kinetic modeling of amyloid binding in humans using PET imaging and Pittsburgh Compound-B. I Cereb Blood Flow Metab 2005, 25:1528-47.

5. Wolk DA, Klunk W: Update on amyloid imaging: from healthy aging to Alzheimer's disease. Curr Neurol Neurosci Rep 2009, 9:345-52.

6. Villemagne $\mathrm{VL}$, Pike KE, Chetelat $\mathrm{G}$, et al: Longitudinal assessment of Abeta and cognition in aging and Alzheimer disease. Ann Neurol 2011, 69:181-92.

doi:10.1186/1479-5876-10-S2-A31

Cite this article as: Price et al:: Positron emission tomography imaging of amyloid-beta plaque deposition: a decade of translation. Journal of Translational Medicine 2012 10(Suppl 2):A31.

\section{Submit your next manuscript to BioMed Central} and take full advantage of:

- Convenient online submission

- Thorough peer review

- No space constraints or color figure charges

- Immediate publication on acceptance

- Inclusion in PubMed, CAS, Scopus and Google Scholar

- Research which is freely available for redistribution

Submit your manuscript at www.biomedcentral.com/submit
C Biomed Central 